\title{
Effects of lower surface ocean pH upon the stability of shallow water carbonate sediments
}

\author{
Sarah Tynan*, Bradley N. Opdyke \\ Research School of Earth Sciences, Building 47, The Australian National University, Acton, ACT, 0200, Australia
}

\section{A R T I C L E I N F O}

\section{Article history:}

Received 13 October 2008

Received in revised form 29 November 2010

Accepted 1 December 2010

Available online 5 January 2011

\section{Keywords:}

Carbon dioxide

Great Barrier Reef

Carbonate sediments

High-Mg calcite

Ocean acidification

\begin{abstract}
A B S T R A C T
It is predicted that surface ocean pH will reach 7.9 , possibly 7.8 by the end of this century due to increased carbon dioxide $\left(\mathrm{CO}_{2}\right)$ in the atmosphere and in the surface ocean. While aragonite-rich sediments don't begin to dissolve until a threshold $\mathrm{pH}$ of $\sim 7.8$ is reached, dissolution from high-Mg calcites is evident with any drop in $\mathrm{pH}$. Indeed, it is high-Mg calcite that dominates the reaction of carbonate sediments with increased $\mathrm{CO}_{2}$, which undergoes a rapid neomorphism process to a more stable, low-Mg calcite. This has major implications for the future of the high-Mg calcite producing organisms within coral reef ecosystems. In order to understand any potential buffering system offered by the dissolution of carbonate sediments under a lower oceanic $\mathrm{pH}$, this process of high-Mg calcite dissolution in the reef environment must be further elucidated.
\end{abstract}

(c) 2010 Elsevier B.V. All rights reserved.

\section{Introduction}

$\mathrm{CO}_{2}$ in the Earth's atmosphere has long played a role in maintaining an equable temperature on the surface of the planet, and is naturally cycled through the Earth's atmosphere, biosphere and hydrosphere. The Earth's oceans and sediments act as the main sink and buffer of atmospheric $\mathrm{CO}_{2}$, and have helped keep the system in a dynamic equilibrium for many millennia. However, anthropogenic perturbation of the Earth's $\mathrm{CO}_{2}$ cycle has resulted in a dramatic increase in atmospheric $\mathrm{CO}_{2}$ concentrations, with a consequent increase of $\mathrm{CO}_{2}$ entering the shallow oceans. Atmospheric $\mathrm{CO}_{2}$ stood at $379 \mathrm{ppm}$ in 2005. Present levels of atmospheric $\mathrm{CO}_{2}$ stand at $\sim 390 \mathrm{ppm}$ (Tans, 2010), with worst case scenarios suggesting levels as high as 660790 ppm by $2100-2150$ (IPCC, 2007).

It is the ocean's calcium carbonate $\left(\mathrm{CaCO}_{3}\right)$ system that controls its $\mathrm{CO}_{2}$ buffering capacity. As the ocean absorbs $\mathrm{CO}_{2}$ carbonic acid is formed (Eq. (1)), which in turn dissociates to form bicarbonate $\left(\mathrm{HCO}_{3}^{-}\right)$and carbonate $\left(\mathrm{CO}_{3}^{2-}\right)$ ions (Eqs. (2) and (3)):

$\mathrm{H}_{2} \mathrm{O}+\mathrm{CO}_{2} \Rightarrow \mathrm{H}_{2} \mathrm{CO}_{3}$

$\mathrm{H}_{2} \mathrm{CO}_{3} \Rightarrow \mathrm{HCO}_{3}^{-}+\mathrm{H}^{+}$

$\mathrm{HCO}_{3} \Rightarrow \mathrm{CO}_{3}^{2-}+\mathrm{H}^{+}$.

Thus, as $\mathrm{CO}_{2}$ is absorbed into the oceans the $\mathrm{pH}$ of the surface seawater is lowered. The normal pH of surface seawater is 8.1-8.2.

\footnotetext{
* Corresponding author. Fax: +6126125 5544.

E-mail address: sarah.tynan@anu.edu.au (S. Tynan).
}

Predictions are that within the next 100 years, absorption of excess $\mathrm{CO}_{2}$ into the oceans could result in lowering the oceanic $\mathrm{pH}$ to 7.9 (Feely et al., 2001) or even 7.8 (Gattuso et al., 1999). Some modelling predictions see a decrease in ocean $\mathrm{pH}$ of 0.7 , which would result in an oceanic pH lower than any seen over the past 300 million years (Caldeira and Wickett, 2003).

$\mathrm{CO}_{2}$ is ultimately absorbed in the oceans through the dissolution of the carbonate minerals calcite, aragonite and high-Mg calcite (Eq. (4)):

$$
\mathrm{CaCO}_{3}+\mathrm{H}_{2} \mathrm{CO}_{3} \Rightarrow \mathrm{Ca}^{2+}+2 \mathrm{HCO}_{3}^{-} \text {. }
$$

This carbonate dissolution occurs largely in the deep, cold regions of the ocean, where calcite is the dominant carbonate mineral. The process of carbonate dissolution in shallow water environments has been considered inconsequential as these waters are generally supersaturated with respect to the carbonate minerals (Andersson et al., 2003). However, saturation states of the carbonate phases are strongly $\mathrm{pH}$ dependent. A decrease in surface ocean $\mathrm{pH}$ will have serious implications for carbonate precipitation and accretion (Jokiel et al., 2008; Hoegh-Guldberg et al., 2007; Hallock, 2005) and also the stability of existing carbonate sediments. Most susceptible will be the organisms whose skeletons are comprised of the less stable minerals aragonite and high-Mg calcite, both of which are abundant in shallow environments (Morse et al., 2006).

High-Mg calcite with a Mg content of $12 \mathrm{~mol} \% \mathrm{Mg}$ has a stability close to or exceeding that of aragonite (Morse et al., 2006; Walter and Morse, 1984), with stability decreasing as the Mg content increases. Organisms that secrete high-Mg calcite, such as encrusting coralline algae, generally have the role of cementing and holding coral reefs 
together, so lower shallow ocean $\mathrm{pH}$ will have a widespread affect on the entire reef community (Hoegh-Guldberg et al., 2007).

While it is accepted that the carbonate dissolution relevant for oceanic $\mathrm{CO}_{2}$ sequestration occurs at depth, there has been some work carried out regarding shallow water dissolution. Attempts to quantify the potential $\mathrm{CO}_{2}$ sink offered by shallow carbonate dissolution have produced a range of results: in the early 1980s, it was calculated that high-Mg calcite dissolution presented a possible sink of $2 \%$ of annual $\mathrm{CO}_{2}$ emissions at a 1980 level (Garrels and Mackenzie, 1981); Sabine and Mackenzie (1991) suggested that carbonate sediments in reef shelves and banks offer a sink of up to $0.05 \mathrm{Gt} /$ year; while calculations from Langdon (2000) produced a sink of $6 \%$ annual oceanic $\mathrm{CO}_{2}$ uptake. Sabine and Mackenzie (1995) calculated that dissolution of aragonite could offer a sink for $2.6 \times 10^{16} \mathrm{~g}\left(2.6 \times 10^{7} \mathrm{Gt}\right)$ of $\mathrm{CO}_{2}$.

Other work has produced evidence of the critical $\mathrm{pH}$ for carbonate dissolution. Analysis of the pore waters of carbonate sediments in the Bahamas found that dissolution occurred in these waters as soon as pH dropped below 8.0 (Morse et al., 1985). Other studies have found that the lower $\mathrm{pH}$ reached simply as a result of natural respiratory and metabolic processes of $\mathrm{CO}_{2}$ release within reef ecosystems is sufficient to enhance carbonate dissolution (Gattuso et al., 1997; Garcia-Pichel, 2006; Yates and Halley, 2006), evidence that a sustained lowering of ocean $\mathrm{pH}$ will cause increased dissolution of carbonate sediments.

This study investigates the effect of a lower ocean $\mathrm{pH}$ resulting from increased $\mathrm{CO}_{2}$ in the surface ocean by attempting to simulate the natural environment through laboratory experiments, using natural carbonate sediments collected from the Great Barrier Reef, Australia.

\section{Methods}

\subsection{Laboratory experiments}

Carbonate sediments were collected via grab sample from two sites at Lizard Island, which is located on the Great Barrier Reef, in northern Queensland, Australia (Fig. 1). Sediments were taken from the lagoon area, from $~ 1$ to $2 \mathrm{~m}$ depth (Lizard Head) and from a beach location (Coconut Beach). Sediments were dried in sunlight, and were not frozen or refrigerated for transport to the laboratory.

The base of a small fish tank $(24 \mathrm{~cm} \times 19.5 \mathrm{~cm} \times 21 \mathrm{~cm})$ was covered with a $1 \mathrm{~cm}$ deep layer of sediment, and the tank filled with natural seawater $(\sim 9360 \mathrm{~mL})$. Mixing of the water was ensured

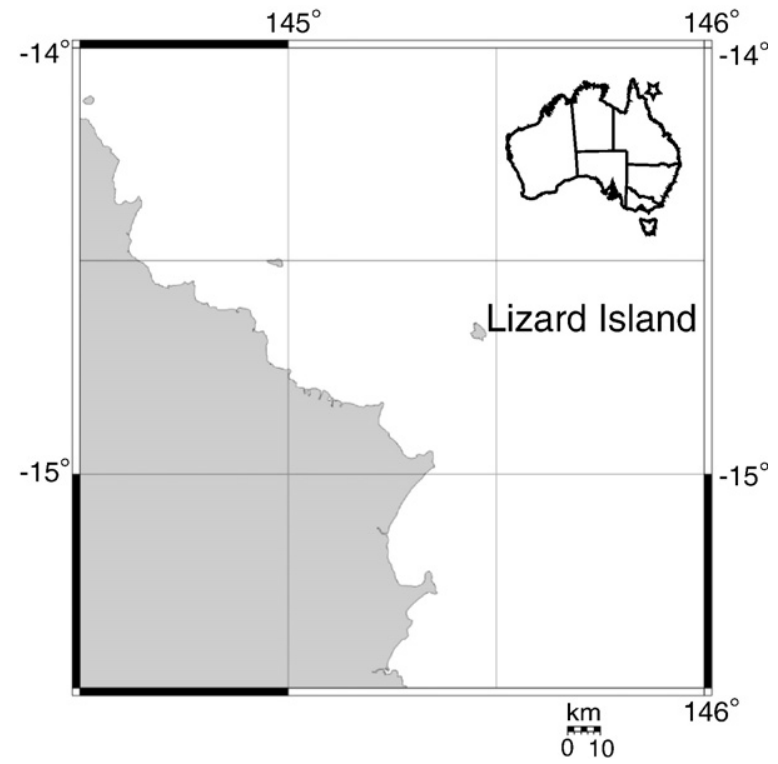

Fig. 1. Location map for Lizard Island. Map created using GMT Online Map Creation website (www.aquarius.geomar.de/omc). through the use of a small submersible aquarium pump. A Perspex lid was placed over the top of the tank to minimise gas exchange between the water and overlying air. The average temperature in the tank was $23.6^{\circ} \mathrm{C}$ with standard deviation of $2.9^{\circ} \mathrm{C}$.

Seawater was collected in clean, well-rinsed containers from Eden and Bateman's Bay, New South Wales, Australia. The water was kept in cold storage, and filtered within $24-48 \mathrm{~h}$ after collection through a $0.45 \mu \mathrm{m}$ Millipore filter to remove any organic matter that could oxidise, and affect the $\mathrm{pH}$ of the seawater. Despite the filtering, the water $\mathrm{pH}$ tended to drop slowly over time. The seawater was discarded if the $\mathrm{pH}$ dropped lower than 7.9.

The Perspex lid over the tank had two ports on the top, where a $\mathrm{pH}$ electrode (SERA 8921-0) and a tube for adding $\mathrm{CO}_{2}$ gas were inserted. The $\mathrm{pH}$ probe and $\mathrm{CO}_{2}$ gas tube were connected to a battery powered pH controller (SERA Seramic $\mathrm{CO}_{2}$ Control System 8005-7), and $\mathrm{CO}_{2}$ cylinder (Soda Stream $\mathrm{CO}_{2} 301,1000 \mathrm{PSI}$, certified $99.9 \%$ pure $\mathrm{CO}_{2}$ ) respectively. The $\mathrm{CO}_{2}$ cylinder was attached to a SERA 8013-2 pressure regulator, which was controlled by a switch within the $\mathrm{pH}$ controller. The system injected $\mathrm{CO}_{2}$ gas according to the desired $\mathrm{pH}$ set on the meter and the valve closed when the $\mathrm{pH}$ probe measured the target $\mathrm{pH}$ in the chamber. The $\mathrm{CO}_{2}$ gas travelled from the cylinder through the tubing to the tank, and then was dispersed in the water through very small diameter gas permeable tubing. Although it was intended to regulate the injection of the $\mathrm{CO}_{2}$ gas such that $\mathrm{pH}$ consistently decreased or remained constant over the duration of the experiment, in some cases, the input of $\mathrm{CO}_{2}$ gas was erratic and thus $\mathrm{pH}$ values fluctuated within some experiments.

Water samples of approximately $120 \mathrm{~mL}$ were taken every one to $3 \mathrm{~h}$ during the day. Where experiments ran for more than one day, samples were not taken throughout the night. Samples were filtered through $4.5 \mu \mathrm{m}$ Millipore filters and stored in plastic acid washed, airtight Nalgene bottles. Experiment duration was varied, depending on the results. Most experiments ran for approximately one week.

The $\mathrm{pH}$ electrode was calibrated prior to each experiment, using TPS pH Buffers 4.00 and 9.23, which are electrometrically referenced to standard buffers traceable to NIST SRM's 186If and 186 IIf. pH measurement accuracy was within 0.1 .

\subsection{Analysis}

\subsubsection{Alkalinity titrations}

Alkalinity titrations were performed immediately following sample collection using a Metrohm 716 DMS Titrino to obtain the concentration of $\mathrm{HCO}_{3}^{-}$and $\mathrm{CO}_{3}^{2-}$, as an indication of dissolution of $\mathrm{CaCO}_{3}$. Titrations were performed to an endpoint $\mathrm{pH}$ of 3.8 and were repeated at least twice, until results were replicated within $1 \%$ $\left(\sim 20 \mu \mathrm{mol} \mathrm{L}^{-1}\right) .0 .01 \mathrm{M} \mathrm{HCl}$ was used for the titrations. The titration procedure was standardised via calibration of the $\mathrm{HCl}$ with $\mathrm{NaOH}$, the concentration of which was determined via titration of a known precise weight of potassium hydrogen phthalate (KHP) AR grade.

\subsubsection{ICP-AES}

Water samples were analysed for $\mathrm{Mg}^{2+}$ and $\mathrm{Ca}^{2+}$ at The Australian National University, using a Varian Vista Pro Axial Geometry Inductively Coupled Plasma Atomic Emission Spectrometer, with an argon plasma maintained by the interaction of a radio frequency (RF) field and ionised argon gas, which operates at approximately $8000 \mathrm{~K}$. Upon the sample's introduction to the plasma, excited cations emit light of varying intensities at known wavelengths throughout the spectrum. The light emitted by the excited atoms is then channelled through a cone to the detector that then measures the intensity of light for the cations of interest at the relevant wavelengths required. To calibrate the instrument, a set of standards of known concentration, along with a blank, are run to obtain intensity/concentration points for each element and zero concentration respectively. The 
calibration standards are reanalysed regularly to account for any instrument drift. The error is $<5 \%$ for the instrument.

The conditions used for this study were:

Calcium wavelength $-315.887 \mathrm{~nm}$

Magnesium wavelength $-279.800 \mathrm{~nm}$

Strontium wavelength $-407.771 \mathrm{~nm}$

Power: $1.00 \mathrm{~kW}$

Plasma flow: $15.0 \mathrm{~L} / \mathrm{min}$

Auxiliary flow: $1.50 \mathrm{~L} / \mathrm{min}$

Nebulizer flow: $0.90 \mathrm{~L} / \mathrm{min}$

Replicate read time: $1.00 \mathrm{~s}$

Instrument stabilization delay: $15 \mathrm{~s}$

Replicates: 3

The standards were prepared from 1000 ppm AccuTrace Reference Standards supplied by AccuStandard Inc.

Water samples were diluted in a $1: 3$ ratio with $2 \% \mathrm{HNO}_{3}$ to accommodate the high $\mathrm{Na}$ concentration of seawater.

\subsection{3. $X R D$}

To determine the mineralogy of each of the sediment samples, $\mathrm{X}$-ray diffraction analysis was carried out with a SIEMENS D501 BraggBrentano diffractometer equipped with a graphite monochromator and scintillation detector, using $\mathrm{CuK} \alpha$ radiation. The sample was ground in an agate mortar in acetone, and supported on a quartz single-crystal low-background holder. The scan range was 2 to $70^{\circ} 2$-theta, at a step width of $0.02^{\circ}$, and a scan speed of $1^{\circ}$ per minute.

The results were interpreted using the SIEMENS software package Diffracplus Eva (2000), and quantitative estimates, to ascertain the proportions of calcite, aragonite and low- and high-Mg calcite, along with the unit cell sizes of the Mg-calcites were performed with the program CSIRO Siroquant 2.5 (2000).

The proportions of calcite, aragonite and $\mathrm{Mg}$-calcite were calculated, along with the unit cell sizes of the Mg-calcite, which was used to estimate the $\mathrm{mol} \% \mathrm{Mg}$ of the sample.

\subsubsection{Grain size analysis}

A representative sample from each sediment type was wet-sieved through a series of sieves, from $400 \mu \mathrm{m}$ to $100 \mu \mathrm{m}$ in $100 \mu \mathrm{m}$ divisions. The different size fractions were then weighed to $+/-0.01 \mathrm{~g}$.

\section{Results}

\subsection{Sediment analysis}

\subsubsection{Mineralogy}

X-ray Diffraction analysis of the sediment samples identified aragonite, high-Mg calcite and calcite, along with insignificant amounts of halite, quartz, and possibly albite. Further analysis using the CSIRO Siroquant 2.5 program (2000) showed that the calcite peaks were slightly offset from the peaks of pure calcite, indicating two different types of high-Mg calcite - a low-Mg calcite with peaks similar to pure calcite, and a more Mg-enriched phase. The Siroquant analysis also yielded approximate quantities of each phase (Table 1), along with the unit cell parameters of the high-Mg calcite, which were used to ascertain the mol\% Mg of the calcite (Mackenzie et al., 1983). The two Mg-calcite phases identified in the sediment types were

Table 1

Mineralogy of each sediment type, as per XRD and Siroquant analysis.

\begin{tabular}{lllll}
\hline & Calcite (\%) & Aragonite (\%) & High-Mg calcite (\%) & Other (\%) \\
\hline Coconut Beach & 3 & 39 & 55 & 3 \\
Lizard Head & 4 & 57 & 36 & 3 \\
\hline
\end{tabular}

Table 2

Grain size analysis of each sediment type.

\begin{tabular}{llllll}
\hline & $\begin{array}{l}0-100 \mu \mathrm{m} \\
(\%)\end{array}$ & $\begin{array}{l}100-200 \mu \mathrm{m} \\
(\%)\end{array}$ & $\begin{array}{l}200-300 \mu \mathrm{m} \\
(\%)\end{array}$ & $\begin{array}{l}300-400 \mu \mathrm{m} \\
(\%)\end{array}$ & $\begin{array}{l}>400 \mu \mathrm{m} \\
(\%)\end{array}$ \\
\hline Coconut Beach & 9.10 & 31.43 & 2.96 & 0.32 & 56.18 \\
Lizard Head & 0.26 & 4.07 & 10.50 & 12.57 & 72.55 \\
\hline
\end{tabular}

found to contain $\sim 9$ and $18.5 \mathrm{~mol} \% \mathrm{Mg}$ respectively. The errors associated with calculation of the unit cell sizes are in the order of 0.001 , and so are unlikely to significantly affect (>1 mol\%) the mol\% $\mathrm{Mg}$ determination of the calcite phases.

As the $\mathrm{mol} \% \mathrm{Mg}$ increases, the stability of the calcite decreases, with calcite of about $12 \mathrm{~mol} \% \mathrm{Mg}$ being roughly equal in stability to aragonite (Walter and Morse, 1984). Approximately 55\% of the Coconut Beach sediment was found to be $18.5 \mathrm{~mol} \% \mathrm{Mg}$-calcite while this phase comprised only $36 \%$ of the Lizard Head sediment (Table 1 ).

3.1.1.1. Grain size analysis. Results from the grain size analysis (Table 2) show that the Coconut Beach sediment contains 35 times more of the smallest $(0-100 \mu \mathrm{m})$ grain size fraction.

\subsection{Laboratory experiments}

\subsubsection{Dissolution vs. precipitation}

For ease of comparison, the results from all of the laboratory experiments were compiled and were plotted to show change in alkalinity as a function of $\mathrm{pH}$. Positive values (increase in alkalinity) are indicative of dissolution, and negative values (decrease in alkalinity) are indicative of precipitation. As replicates were repeated to within $1 \%\left(\sim 20 \mu \mathrm{mol} \mathrm{L}^{-1}\right)$, this error will translate to a range of $\Delta$ alkalinity of $0+/-20 \mu \mathrm{mol} \mathrm{L}{ }^{-1}$ in which values likely do not represent any real significant change in alkalinity. Fig. 2 shows the range of results produced by the various experiments for each sediment type.

The vast majority of values from the Lizard Head sediment experiments plot below the zero line (Fig. 2a). It is evident that even at lower $\mathrm{pH}$ precipitation dominates the system for this sediment type.
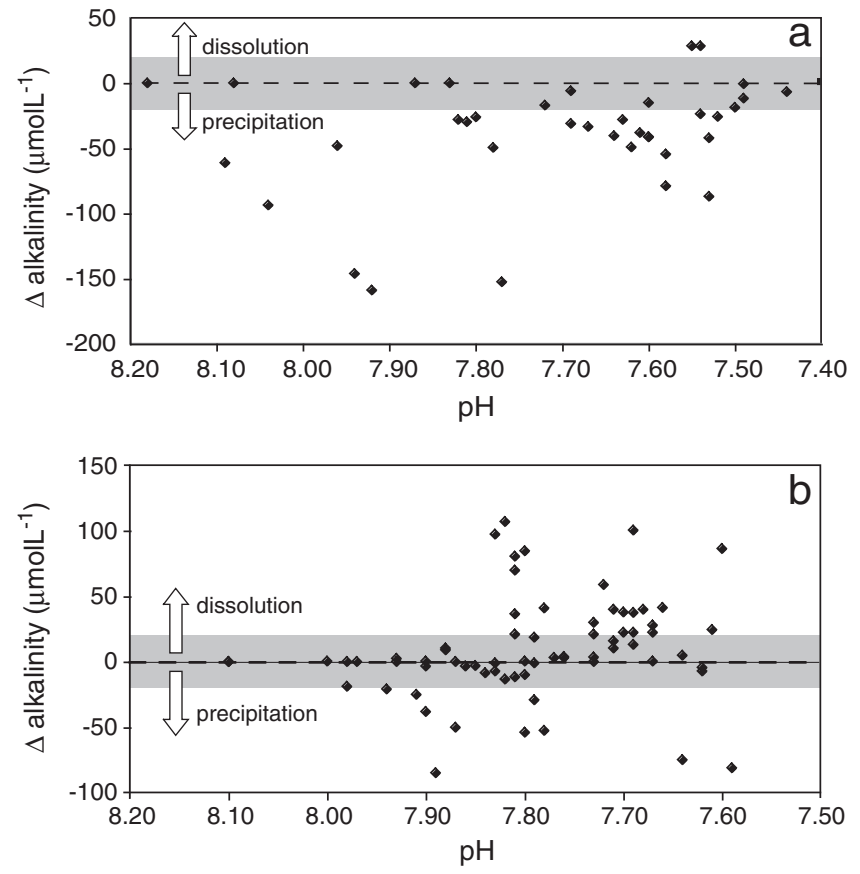

Fig. 2. Change in alkalinity as a function of $\mathrm{pH}$ from experiments using a. Lizard Head sediments and b. Coconut Beach sediments. Values that lie above the zero line indicate dissolution of $\mathrm{CaCO}_{3}$, values below the zero line indicate precipitation of $\mathrm{CaCO}_{3}$. 
In contrast, most of the Coconut Beach experiments show a relatively clear dissolution path (Fig. 2b). At pH greater than 7.8, precipitation dominates the system. Below this value, while there is still some precipitation, dissolution is clearly starting to occur. The majority of the highly negative values in the Coconut Beach plot come from a single experiment, which shows a dissolution pattern much closer to those of the Lizard Head sediment experiments.

\subsubsection{Re-precipitation of a low-Mg calcite}

In some experiments, where alkalinity decreases as a result of precipitation, there is a corresponding increase in $\mathrm{Mg}^{2+}$ and $\mathrm{Ca}^{2+}$. This indicates dissolution of a high-Mg calcite and re-precipitation of another calcite of lower Mg content (Fig. 3). This phenomenon is not evident in all of the experiments, but mainly those which sediments that contain a high proportion of high-Mg calcite. Alkalinity, $\mathrm{Mg}^{2+}$, and $\mathrm{Ca}^{2+}$ data are reported in a Supplemental data table.

Furthermore, the proportions of $\mathrm{Mg}^{2+}$ and $\mathrm{Ca}^{2+}$ that are produced by the dissolution reactions are not consistent throughout the experiments. However, common to all the experiments that show dissolution is an unexpectedly high amount of $\mathrm{Mg}^{2+}$ as compared to $\mathrm{Ca}^{2+}$, as shown in Fig. 4.

\section{Discussion}

Although the Lizard Head sediments were air-dried prior to running the experiments, it is possible that some remnant organisms were still present in the material, resulting in some biologicallyinduced $\mathrm{CaCO}_{3}$ precipitation, which could account, at least in part, for the alkalinity signal exhibited in Fig. 2a.

Another, possibly more important, factor in the enhanced dissolution measured in the Coconut Beach sediment experiments is the markedly higher (55\% compared to $36 \%$ ) proportion of high-Mg

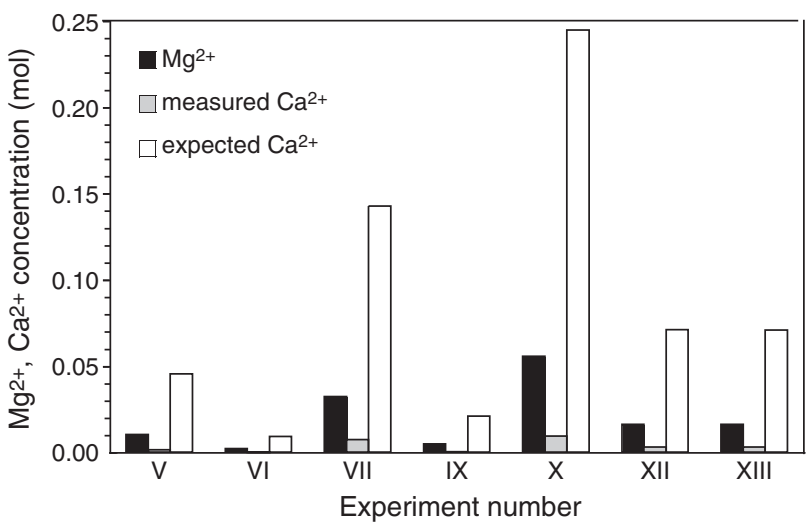

Fig. 4. Comparison of $\mathrm{Mg}^{2+}$, measured $\mathrm{Ca}^{2+}$ and expected $\mathrm{Ca}^{2+}$ (calculated from dissolution of $18.5 \mathrm{~mol} \% \mathrm{Mg}$-calcite).

calcite in the Coconut Beach sediment, emphasising the importance of high-Mg calcite in any reef sediment dissolution regime.

Additionally, the Coconut Beach sediment has over 10 times the amount of the $<100 \mu \mathrm{m}$ grain size fraction. This could also be a factor in the enhanced dissolution, although it has been proposed that grain size does not play a significant role in enhancing dissolution until the grains have a diameter smaller than $0.1 \mu \mathrm{m}$ (Bathurst, 1975). Unfortunately, analysis to this precision was not conducted on any of the samples used in this project.

The results from the different experiments are somewhat varied. Not all experiments show dissolution of carbonate, and in the experiments where dissolution did occur, it occurred in markedly different amounts. Why there is such disparity in the results of the various experiments is unclear, though the nature of the experiments
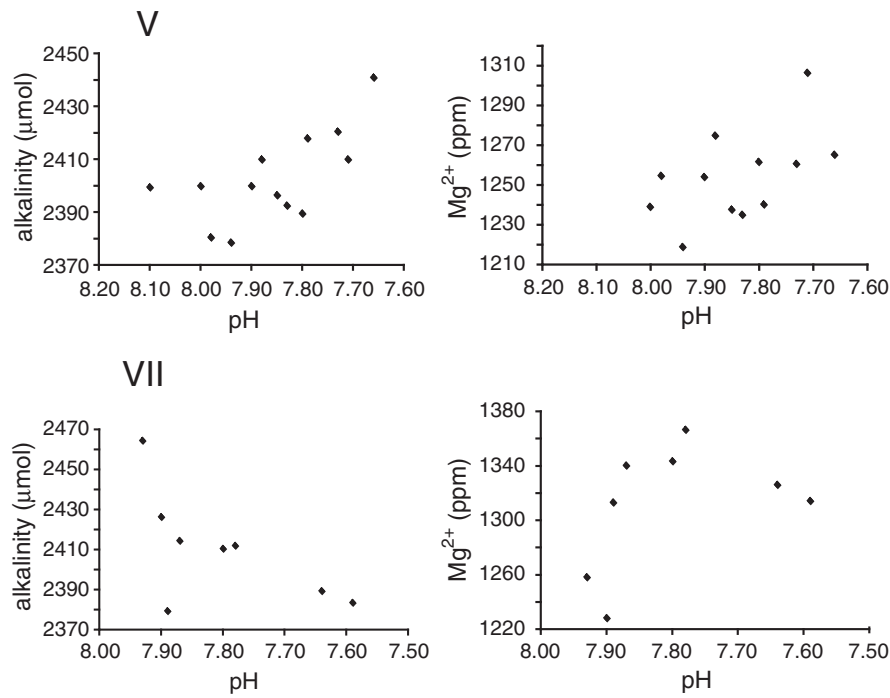

IX
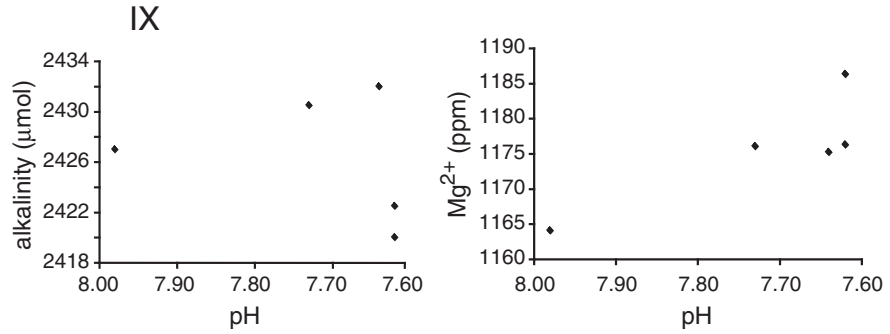
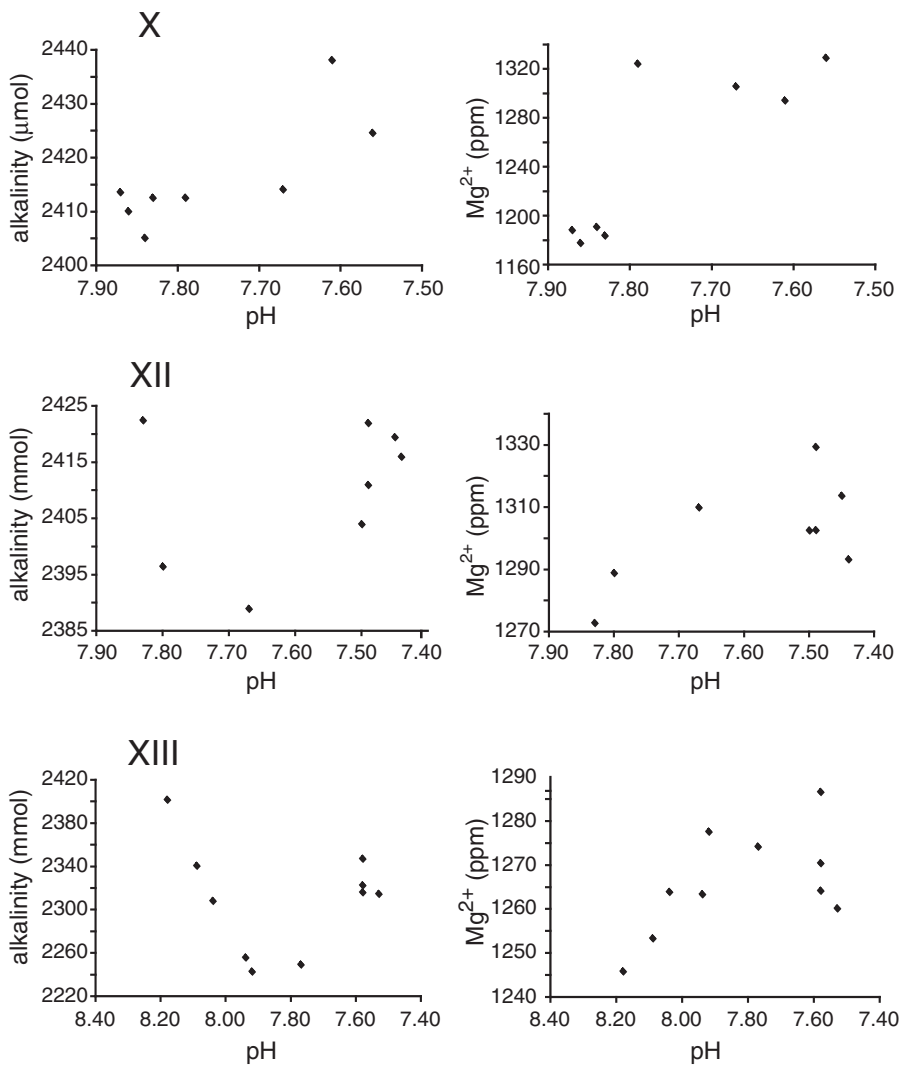

Fig. 3. Results from experiments showing an initial decrease in alkalinity, accompanied by an increase in $\mathrm{Mg}^{2+}$. 
dictates that the sediment samples will not be homogenous across all of the experiments, which could account for differences in the results. Clearly evident is the dominance of high-Mg calcite in any dissolution signal seen at these $\mathrm{pH}$ values.

The process is further complicated by the dissolution behaviour of the high-Mg calcite. The experiments that showed an increase of $\mathrm{Mg}^{2+}$ in the water column, accompanied by a decrease in alkalinity, indicate a very rapid dissolution of a high-Mg calcite with subsequent re-precipitation of another calcite of lower $\mathrm{Mg}$ content. This process has been documented in previous studies (Tribble et al., 1995). Dissolution of the high-Mg calcites with subsequent re-precipitation of a lower-Mg calcite will offer a quantifiable buffering capacity for shallow-ocean "acidification".

Further indication of this neomorphism or stabilisation process is the disproportionate amounts of $\mathrm{Mg}^{2+}$ and $\mathrm{Ca}^{2+}$ released into the water column. If the mol\% $\mathrm{Mg}$ of the high-Mg calcite is taken to be $18.5 \%$, as indicated by the Siroquant 2.5 (2000) analysis, then proportions of $\mathrm{Mg}$ and Ca produced by dissolution of this phase should be in the ratio of 1:4 (18.5:81.5). However, as shown in Fig. 4, this is not the case, with $\mathrm{Mg}$ :Ca ranging from 4.4:1 to $12.9: 1$. This excess of $\mathrm{Mg}^{2+}$ indicates that as both $\mathrm{Mg}^{2+}$ and $\mathrm{Ca}^{2+}$ are produced from the dissolution of the high-Mg calcite, much of the $\mathrm{Ca}^{2+}$ is sequestered by the rapid precipitation of a more stable low-Mg calcite. While these results perhaps do not yield a viable quantitative assessment of this reaction, it is clearly evident that a neomorphism from high-Mg calcite to a more stable low-Mg calcite process takes place, and that the reaction takes place quickly, i.e., on a timescale of hours. This reiterates that the high-Mg calcite-precipitating organisms, such as coralline algae, will be among the first to show the detrimental effects of a lower oceanic $\mathrm{pH}$.

It is necessary to note that the Coconut Beach sediments contain an unusually high proportion of high-Mg calcite, with an unusually high mol\% Mg. Reef sediments around the globe are heterogeneous, and quantification of the proportions of high-Mg calcite, and the $\mathrm{mol} \% \mathrm{Mg}$ of these calcites is required to assess the effects of the neomorphism of the high-Mg calcite to low-Mg calcite resulting from a drop in ocean $\mathrm{pH}$.

Another consideration is the importance of biological activity in regulating the processes of precipitation and dissolution in reef systems (Leclerq et al., 2002; Garcia-Pichel, 2006; Tribollet et al., 2006; Yates and Halley, 2006), and the need to place the various thermodynamic and chemical studies carried out regarding carbonate dissolution in the context of the complex natural system. Indeed, Morse et al. (2006) provide an excellent synopsis of high-Mg calcite and outline some of the complexities and limitations of using theoretical and inorganic calcite experimental data to interpret the natural world.

\section{Conclusion}

From the results of this study, it is evident that a decrease in surface ocean $\mathrm{pH}$ to levels such as 7.9 or 7.8 due to rising atmospheric $\mathrm{CO}_{2}$ levels will lead to enhanced dissolution of carbonate sediments in shallow water systems. Significant dissolution of aragonite or low-Mg calcite rich sediment, as indicated by an increase in alkalinity in the experiments, began at a $\mathrm{pH}$ of 7.8. However, neomorphism of high$\mathrm{Mg}$ calcite to a more stable, low-Mg calcite occurred as soon as $\mathrm{pH}$ began to fall. Organisms that produce high-Mg calcite will become particularly vulnerable as the surface ocean $\mathrm{pH}$ drops, and there could be a resultant change in reef biota and a reorganisation of reef structure.

The reaction of high-Mg calcite to rapidly restabilise to a lower-M g calcite as ocean $\mathrm{pH}$ drops will potentially provide an as yet unquantified but significant buffer to ocean "acidification". A more comprehensive understanding of the dissolution behaviour of high-Mg calcite, and indeed, the abundance and distribution of high-Mg calcite is necessary in order to predict more accurately the affects of lower oceanic $\mathrm{pH}$ and the response of the shallow ocean carbonate system.

Supplementary materials related to this article can be found online at doi: 10.1016/j.scitotenv.2010.12.007.

\section{Acknowledgements}

The authors would like to thank the staff of the Lizard Island and Heron Island Research Stations, the Australian Museum and the Great Barrier Reef Marine Park Authority. The project was supported by the Department of Earth and Marine Sciences (now the Research School of Earth Sciences) of the Australian National University. Thanks also to Ulli Troitzsch and Linda McMorrow for assistance with sample analysis.

\section{References}

Andersson AJ, Mackenzie FT, Ver LM. Solution of shallow water carbonates: an insignificant buffer against rising $\mathrm{CO}_{2}$. Geology 2003;31:513-6.

Bathurst RGC. Carbonate sediments and their diagenesis. Amsterdam: Elsevier; 1975.

Caldeira K, Wickett ME. Anthropogenic carbon and ocean pH. Nature 2003;425:365.

Feely RA, Sabine CL, Takahashi T, Wannikhof R. Uptake and storage of carbon dioxide in the ocean. The global $\mathrm{CO}_{2}$ survey. Oceanogr Magn 2001;14:18-32.

Garcia-Pichel F. Plausible mechanisms for the boring on carbonates by microbial phototrophs. Sediment. Geol. 2006;185:205-13.

Garrels RM, Mackenzie FT. Some aspects of the role of the shallow ocean in global carbon dioxide uptake. Atlanta, Georgia, United States: US Department of Energy; 1981

Gattuso J-P, Payri CE, Pichon M, Delesalle B, Frankignouelle M. Primary production, calcification, and air-sea $\mathrm{CO}_{2}$ fluxes of a macroalgal-dominated coral reef community (Moorea, French Polynesia). J Phycol 1997;33:729-38.

Gattuso J-P, Allemand D, Frankignouelle M. Photsynthesis and calcification at cellular organismal and community levels in coral reefs: a review on interactions and controls by carbonate chemistry. Am Zool 1999;39:160-83.

Hallock P. Global change and modern coral reefs: new opportunities to understand shallow-water carbonate depositional processes. Sediment Geol 2005;175:19-33.

Hoegh-Guldberg O, Mumby PJ, Hooten AJ, Steneck RS, Greenfield P, Gomez E, Harvell CD, Sale PF, Edwards AJ, Caldeira K, Knowlton N, Eakin CM, Iglesias-Prieto R, Muthiga N, Bradbury RH, Dubi A, Hatziolos ME. Coral Reefs Under Rapid Climate Change and Ocean Acidification. Science 2007;318:1737-42.

IPCC. Summary for policymakers. In: Metz B, Davidson OR, Bosch PR, Dave R, Meyer LA, editors. Climate Change 2007: Mitigation. Contribution of Working Group I to the Fourth Assessment Report of the Intergovernmental Panel on Climate Change. Cambridge United Kingdom and New York, NY, USA: Cambridge University Press: 2007. p. 2.

Jokiel PL, Rodgers KS, Kuffner IB, Andersson AJ, Cox EF, Mackenzie FT. Ocean acidification and calcifying reef organisms: a mesocosm investigation. Coral Reefs 2008;27:473-99.

Langdon C. Review of experimental evidence for effects of $\mathrm{CO}_{2}$ on calcification of reef builders. In: Kasim Moosa M, Subagjo Soemodihardjo, Aprilani Soegiarto, Kasijan Romimohtarto, Anugerah Nontji, Soekarno Suharsono, editors. Ninth Int. Coral Reef Symp. Proc. 23-29 October 2000, Bali, Indonesia; 2000. p. 1091-8.

Leclerq N, Gattuso J-P, Jaubert J. Primary production, respiration, and calcification of a coral reef mesocosm under increased $\mathrm{CO}_{2}$ partial pressure. Limnol Oceanogr 2002;47:558-64.

Mackenzie FT, Bischoff WD, Bishop FC, Loijens M, Schoonmaker J, Wollast R. Magnesian calcites: low-temperature occurrence, solubility and solid-solution behaviour. In: Reeder RJ, editor. Carbonates: mineralogy and chemistry. USA: Mineralogy Society of America; 1983. p. 97-144.

Morse JW, Zullig JJ, Bernstein LD, Millero FJ, Milne P, Mucci A, et al. Chemistry of calcium carbonate-rich shallow water sediments in the Bahamas. Am J Sci 1985;285: $147-85$.

Morse JW, Andersson AJ, Mackenzie FT. Initial responses of carbonate-rich shelf sediments to rising atmospheric $\mathrm{PCO}(2)$ and "ocean acidification": Role of high Mgcalcites. Geochim Cosmochim Acta 2006;70:5814-30.

Sabine $\mathrm{CL}$, Mackenzie FT. Oceanic sinks for anthropogenic $\mathrm{CO}_{2}$. Int J Energy Environ Econ 1991;1:118-27.

Sabine CL, Mackenzie FT. Bank-derived carbonate sediment transport and dissolution in the Hawaiian archipelago. Aquat Geochem 1995;1:189-230.

NOAA/ESRL www.esrl.noaa.gov/gmd/ccgg/trends/ site accessed 16 August 2010.

Tribble JS, Arvidson RS, Lane III M, Mackenzie FT. Crystal chemistry, and thermodynamic and kinetic properties of calcite, dolomite, apatite, and biogenic silica: applications to petrologic problems. Sediment Geol 1995;95:11-37.

Tribollet A, Atkinson AJ, Langdon C. Effects of elevated $p \mathrm{CO}_{2}$ on epilithic and endolithic metabolism of reef carbonates. Global Change Biol 2006;12:2200-8.

Walter LM, Morse JW. Magnesian calcite stabilities: a reevaluation. Geochim Cosmochim Acta 1984;48:1059-69.

Yates KK, Halley RB. Diurnal variation in rates of calcification and carbonate sediment dissolution in Florida Bay. Estuaries Coasts 2006;9:24-39. 